
\title{
3 Researchspuare \\ Local Perception of Ecosystem Services and their Conservation in Sudanian Savannas of Burkina Faso (West Africa)
}

\section{Assétou Nabaloum ( $\square$ asnab2000@gmail.com )}

Joseph Ki-Zerbo University: Universite Joseph Ki-Zerbo https://orcid.org/0000-0002-2855-5169

Dethardt Goetze

University of Rostock: Universitat Rostock

Amadé Ouédraogo

Joseph Ki-Zerbo University: Universite Joseph Ki-Zerbo

Stephan Porembski

University of Rostock: Universitat Rostock

Adjima Thiombiano

Joseph Ki-Zerbo University: Universite Joseph Ki-Zerbo

\section{Research Article}

Keywords: Indigenous knowledge, Land use, Plant vulnerability, Sustainable management, sociocultural groups.

Posted Date: August 19th, 2021

DOI: https://doi.org/10.21203/rs.3.rs-818596/v1

License: (c) (1) This work is licensed under a Creative Commons Attribution 4.0 International License.

Read Full License

Version of Record: A version of this preprint was published at Journal of Ethnobiology and Ethnomedicine on February 19th, 2022. See the published version at https://doi.org/10.1186/s13002022-00508-w. 


\section{Abstract}

Context: In Burkina Faso, Sudanian savannas are important ecosystems for plant diversity conservation. However, population migration from the north due to desertification and insecurity has increased human density and caused an intensification of anthropogenic pressure on southern savannas. This study aims to investigate local population's knowledge on ecosystem services (ES), and perception on their conservation.

Method: Individual semi-structured interviews focused on informants' knowledge on ES and ecosystem conservation issues were conducted. Informants were selected according to the sociocultural groups and sex in three land use intensity levels: the communal area of Dano (CAD), the Total Wildlife Reserve of Bontioli (TWRB) and the Game Ranch of Nazinga (GRN). The use value and vulnerability index of each plant species were determined. Cluster analysis and principal component analysis were conducted to identify the particular knowledge of the different groups.

Results: Overall, 163 plant species were cited for fifteen ES. Provisioning services were the most cited (100\%) followed by regulating services $(92.47 \%)$. Entire plants were exclusively used in conservation services (protection against wind, for shading, soil fertility, erosion prevention, tourism and religion). The ten species which contribute most to ES were Vitellaria paradoxa, Parkia biglobosa, Diospyros mespiliformis, Adansonia digitata, Lannea microcarpa, Faidherbia albida, Khaya senegalensis, Afzelia africana, Ficus sycomorus, Pterocarpus erinaceus. Seven of them were identified as highly vulnerable. Migrants and natives around the GRN share the same knowledge, while migrants in the TWRB used the ES only to a small extent due to restricted contact with the native population. Migrants and natives of GRN have more knowledge on crafts services while the native of CAD and TWRB exploit the services that sustain the quality of the agricultural land and insure their primary needs. To reduce further degradation, the different communities suggested unanimously raising awareness on the importance of biodiversity and ecosystem preservation. The most quoted motivations to preserve ecosystems were vegetation sustainability and village development.

Conclusion: This study documented important local knowledge-based information to guide domestication of local multipurpose species and the initiation of communities to practice best management strategies for sustainable conservation of biodiversity.

\section{Background}

Ecosystem services (ES) are defined as the goods and services obtained by the human population from ecosystems, directly or indirectly, to assure its well-being [1]. ES can be classified in four main categories. The supporting services derived from general functioning of an ecosystem, the regulating services correspond to the direct services of ecological functions on site, and provisioning and cultural services refer to direct services of obtaining goods and social and spiritual wellbeing from ecosystems. While the provisioning services provide finished products of ecosystems (such as food, fodder, wood, medicinal 
compounds ...), the non-material cultural services allow for developing and enriching knowledge systems, social relationships and aesthetic values [2].

In West African semi-arid areas, local populations strongly depend on plant resources for their daily needs $[3,4,5,6]$. Local people consider savanna ecosystems as their own good. In fact, savanna ecosystems are considered as granary, pharmacy, pasture, place of religious worship, and source of the strength of their territory [7]. Ecosystem functions and services result not only from good ecosystem health, but also from the use that populations have made in various biogeographic and geo-economic contexts [8].

In Sudanian savanna ecosystems, climate and soil characteristics are favorable to the development of a diversified and dense vegetation cover [9]. In the semi-arid context of Burkina Faso, Sudanian savannas constitute a particular hot-spot of plant species diversity [10,11]. Zizka et al. [10] revealed that the Sudanian zone of Burkina Faso shelters $71 \%$ of the total plant species richness of the country and more than half of them are rare. However, migration of populations from the North, fleeing desertification and climate change consequences for arable lands to the south during recent decades has caused an increase in population density in Sudanian savanna areas. In addition, security problems in the northern and eastern regions of the country due to terrorist attacks have caused a new wave of migration. Thus, the population density in the Southwest region, for example, has increased from 27.3 to 51.66 inhabitants $/ \mathrm{km}^{2}$ from 1985 to 2019 [12]. This population growth has an immediate consequence such as intensification of anthropogenic pressure on plant resources and protected areas [13]. From 1984 to 2013, Dimobe et al. [14 and 15] noted a significant decrease of natural vegetation, followed by an expansion of croplands in the South-Sudanian zone of the country. In addition, the same authors highlighted habitat fragmentation in the Sudanian protected areas [15].

The inclusive sustainable management of plant resources by the forest authority in collaboration with local populations could be a response to the strong anthropogenic pressure that ecosystems are facing. In fact, the fundamental ecological role of forests is as important as their economic and social roles for the local populations [3]. The indigenous people play a crucial role in biodiversity conservation through their traditional knowledge on species and habitats and their socioeconomic and symbolic practices as well [16]. However, many local populations suffer from the consequences of large development projects and natural resources exploitation. Among these consequences are land expropriations, loss of identity, language and culture [16]. Thus, local populations adapt their use to the changes they perceive [8] in different ecosystems. They know that their survival essentially depends on their adaptation to the socioenvironmental impact of climate change [17]. Better conservation of ecosystems requires good mastering of endogenous and scientific knowledge [7]. In addition, with decentralization processes and population self-management, the local scale is the relevant geographic and socio-economic space for conducting participatory development policies [18]. According to Holou and Sinsin [19], it would allow for answering one of the major concerns of African countries which is the rational and sustainable management of natural resources. 
In the last decade, research questions on ES have been increasingly focused on the provisioning services $[20,21,4,5,22,23,24,25]$. In order to design effective vegetation management that prevents damage and promote the wellbeing of local people, it is important to take into account the needs of the latter. Thus, the present study aims to (i) understand local population's knowledge on ecosystem services provided by plant species, (ii) identify factors that influence this knowledge, and (iii) understand local perceptions of sustainable management of plant communities.

\section{Methods}

\section{Study area}

The study was carried out in the South-Sudanian phytogeographical sector of Burkina Faso [9]. The sampling areas were chosen based on variable land-use intensity and were classified according to a three-point scale with high, medium and low land-use intensity [26]. The classification was made taking into account land-use/land cover data via multi-temporal Landsat images (for methodological details see $[14,15])$. The communal area of Dano (CAD), located in the Southwestern region of Burkina Faso and characterized by agrosystems and grazing land corresponds to the high land-use intensity level (Fig. 1). The total wildlife reserve of Bontioli (TWRB), also located in the Southwestern region, consists of a protected area of IUCN category I under several human pressures and corresponds to the moderate landuse intensity level. The game ranch of Nazinga (GRN) and its ZOVICs (village hunting zones), which are protected areas of IUCN category $\mathrm{VI}$, devoted to hunting and located in the South-central region, correspond to the low land-use intensity level.

The vegetation types in the study area are shrub savannas, tree savannas, woodland savannas, woodland, dry forest and gallery forests [27]. Dominant woody species are Vitellaria paradoxa C.F. Gaertn, Terminalia laxiflora Engl. \& Diels, Terminalia macroptera Guill. \& Perr., Combretum glutinosum Perr. ex DC., Combretum micranthum G.Don, Combretum adenogonium Steud. Ex A.Rich., Combretum collinum Fresen., Anoeissus leiocarpa (DC.) Guill. \& Perr., Detarium microcarpum Guill. \& Perr., Piliostigma thonningii (Schum.) Milne-Redhead, Isoberlinia doka Craib \& Stapf and Lannea acida A. Rich. The dominant grass species were Andropogon gayanus Kunth, Hypparhenia rufa (Nees) Stapf, Loudetia togoensis (Pilger) C.E. Hubbard and Schizachyrium sanguineum (Retz.) Alston [14, 15].

The climate of the study area is Sudanian with a unimodal rainy season of 5 to 6 months from May to September or October. The mean annual rainfall during a 30-year period (1986-2015) is $1048.73 \pm 146.7$ $\mathrm{mm}$. The mean temperature for this same period is $28.1 \pm 2.15^{\circ} \mathrm{C}$ (National Direction of Meteorology of Burkina Faso).

The native sociocultural groups are Dagara and Pougouli in CAD, Dagara in TWRB and Kassena in GRN. The dominant non-native sociocultural group encountered in all sites are Mossi which have moved to these areas to practice agriculture in the favor of fertile soils, and recently for gold panning. Agriculture, livestock and gold panning constitute the main human activities in the study area. 


\section{Sampling Design And Data Collection}

Seventeen villages were randomly selected in the three study sites following a random sampling scheme. Their distribution was seven villages in CAD, five around TWRB and five around GRN. The selection of informants was stratified, based on sociocultural groups (Dagara, Pougouli, Mossi, Kassena) and sex [28]. Among these sociocultural groups, Mossi were migrants and the other ones are indigenous. Individual semi-structured interviews were conducted from December 2016 to March 2017 to collect the data following a questionnaire. In each village and for each sociocultural group, ten informants of at least 20 years old were interviewed making a total sample of 240 informants. Interviews were conducted in the informants' local language translated by a local translator. Informants were asked with their consent to list the plant species they use and for each used species the services rendered and the used organs were recorded. Informants were also requested about availability and dynamics of the plant species, the factors of these dynamics, the solutions in case of regression and the motivations to conserve biodiversity. Each informant classed the items of suggested solution and motivation to conserve biodiversity by preference order. For identifying the plant species cited, at the end of each interview the "walk-in-the woods" method was used. This method consisted in field visits with some members of the community who have good knowledge about plant species [29]. During the field visit, fresh samples of cited species were collected and pressed for identification using the floras of Berhaut [30], Lebourgeois et Merlier [31], Poilecot [32] and the field handbook of Arbonnier [33].

\section{Data Analyses}

First, useful species cited by informants were ranked according to the fifteen most cited ES of the four categories of provisioning, regulating, cultural and supporting ES [1, 5]. Ethnobotanical indices were calculated to assess the importance of services provided by each species. They are:

- the relative frequency of organ citation (RFO) with the adapted formula from Camou-Guerrero et al. [34] RFO = (Nuh / Ntu) $\square 100$

where Nuh represents the number of citations of uses of the organ and Ntu the number of citations of all the organs in each ES;

- the relative frequency of service citation (RFS) RFS = (Nuh / Ntu) $\square 100$

where Nuh represents the number of citations of one service and Ntu the number of citations of all the ecosystem services in the land use pattern.

- the actual UV index of a species (mean of the number of distinct actual uses reported per informant) $U V=\sum U i / U t$ 
where Ui denotes the number of different uses of a species and Ut the total number of people who cited the species

The result of species use values allowed for selecting the ten most used species to estimate the sociocultural groups' knowledge on ES and the impact of their use on their availability. The uses of the ten most used species were considered in order to take into account the repetition of the variables.

Second, a nonparametric test of Kruskal-Wallis at the $5 \%$ threshold was carried out to compare the different services quoted by the populations according to land use intensity and sociocultural groups; where $\chi^{2}$ represents the approximate value of modal distribution. The degree of freedom, D.f $=$ effectif- 1 and a P-value $\otimes 0.05$ indicate a significant difference in results. Thus, a hierarchical classification (HCPC) cluster analysis was carried out to determine the degree of similarity between the knowledge of different sociocultural groups; afterwards a principal component analysis (PCA) was performed to assess the links between sociocultural groups (individuals) and knowledge on ES (initial variables).

Third, the conservation status of the ten most used species was determined by the vulnerability index calculation [35] which is the average of the highest values of seven selected parameters (Table 1). According to Betti [35], if $\mathrm{VI}<2$, the species is assumed to be weakly vulnerable, if $2 \leq \mathrm{VI}<2.5$, the species is moderately vulnerable, and if $\mathrm{VI} \geq 2.5$, the species is highly vulnerable. A nonparametric test of KruskalWallis at the $5 \%$ threshold was also performed across sociocultural groups to assess the consensus of interviewees on factors of ecosystem degradation, recommended solutions and motivations for preserving ES. The analyses were processed with $\mathrm{R}$ software [36].

Table 1

Applied parameters of the vulnerability index

\begin{tabular}{|c|c|c|c|}
\hline Parameters & 1 (Low scale) & 2 (Average scale) & 3 (High scale) \\
\hline Use frequency (N1) & $N 1<20 \%$ & $20 \% \leq \mathrm{N} 1<60 \%$ & $N 1 \geq 60 \%$ \\
\hline Number of uses (N2) & $\mathrm{N} 2<2$ & $2 \leq \mathrm{N} 2 \leq 4$ & $\mathrm{~N} 2 \geq 5$ \\
\hline Plant parts used (N3) & Leaves, latex & Fruits, branches & $\begin{array}{l}\text { Wood, seeds, bark, roots, } \\
\text { flowers }\end{array}$ \\
\hline Biotope of plant (N4) & Ruderal, gardens field & Secondary forest & $\begin{array}{l}\text { Primary or undisturbed } \\
\text { forest }\end{array}$ \\
\hline Collection mode (N5) & $\begin{array}{l}\text { Collection on the } \\
\text { ground }\end{array}$ & & Collection on the tree, cutting \\
\hline $\begin{array}{l}\text { Development stage } \\
\text { (N6) }\end{array}$ & Old, senescent & Adult & Young \\
\hline $\begin{array}{l}\text { Relative frequency } \\
\text { (N7) }\end{array}$ & $\mathrm{Rf} \geq 2 / 3 \mathrm{Fm}$ & $\begin{array}{l}1 / 3 \mathrm{Fm} \leq \mathrm{Rf}<2 / 3 \\
\mathrm{Fm}\end{array}$ & $\mathrm{Rf}<1 / 3 \mathrm{Fm}$ \\
\hline
\end{tabular}




\section{Results}

\section{Diversity of used plant species and ecosystem services}

In the seven villages of CAD, the informants were all indigenous Dagara and Pougouli. Mossi migrants were met in two camps in five TWRB villages and in all five GRN villages (Table 2).

163 species including 129 woody species and 34 herbaceous species (belonging to 122 genera and 42 families) were recorded as major ES providing species to local populations. In all categories of land-use intensity, the most dominant families were the Fabaceae (35 species), Poaceae (17 species) and Malvaceae (13 species). Each ES concerned a great diversity of plant species. At least 60 species were used in $10 \mathrm{ES}$. Provisioning services were accomplished with the highest number of species (Fig. 2) and were the most cited (67\%) by the informants. These services concerned medicinal use (120 species), fodder (76 species) and food supply (75 species). The species used in these three services had multipurpose uses. Diospyros mespiliformis, Khaya senegalensis, Vitellaria paradoxa and Saba senegalensis were quoted for $14 \mathrm{ES}$.

When considering the overall level, the relative frequencies of plant species use varied significantly between the different ES $\left(\chi^{2}=1849.6 ; \mathrm{DI}=14 ; \mathrm{P}\right.$-value < 0,0001). By far the most species were quoted for food supply (25.98\%) and medicinal use (20.89\%), followed by fodder $(7.33 \%)$, craft $(6.10 \%)$ and energy supply $(6.09 \%)$, which are all provisioning services (Fig. 3). Protection against wind (6.08\%) and shading (6\%) (regulating service) were important services, too.

The relationships between ES and plant organs used for them (Fig. 4) showed that the entire plant was exclusively (100\%) cited for six ES, notably soil fertility (supporting services), religion, tourism (cultural services), and shading, protection against wind and erosion prevention (regulating services).

Wood was exploited for the three provisioning services energy supply (100\%), building (100\%) and craft (65\%). Plant stalks were only used for craft and ceremony services. Plant leaves and fruits were cited both for provisioning (food, fodder supply, medicinal use), regulating (pest control, water purification) and cultural (ceremonies) services with varying relative frequencies. Fruits were cited more often $(70 \%)$ for food service. Flowers and seeds were used for food only. The highest number of organs (5) was cited for medicinal services, including bark and roots.

The use values (UV) computed for all quoted species showed that many species were exploited for several services. Woody species were the plant category with the highest UV (i.e. the most used species). Vitellaria paradoxa was the species with the highest use value in our study sites. For the herbaceous species, the three most used ones were Andropogon gayanus Kunth, Rottboellia cochinchinensis (Lour.) Clayton and Hyptis spicigera Lam. In general, the ten species with the highest use values were in decreasing order: Vitellaria paradoxa, Parkia biglobosa, Diospyros mespiliformis, Adansonia digitata, Lannea microcarpa, Faidherbia albida, Khaya senegalensis, Afzelia africana, Ficus sycomorus, and Pterocarpus erinaceus (Table 3). 
Table 2

Sociodemographic characteristics of the informants

\begin{tabular}{|llll|}
\hline Study sites & CAD & TWRB & GRN \\
$\begin{array}{l}\text { Number of } \\
\text { villages }\end{array}$ & 7 & 5 & 5 \\
$\begin{array}{l}\text { Sociocultural } \\
\text { group }\end{array}$ & $\begin{array}{l}\text { Dagara (71\%), Pougouli } \\
(29 \%)\end{array}$ & $\begin{array}{l}\text { Dagara (71\%), Mossi } \\
(29 \%)\end{array}$ & $\begin{array}{l}\text { Kassena (50\%), Mossi } \\
(50 \%)\end{array}$ \\
\hline Gender & $\begin{array}{l}\text { Male (50\%); Female } \\
(50 \%)\end{array}$ & $\begin{array}{l}\text { Male (50\%); Female } \\
(50 \%)\end{array}$ & $\begin{array}{l}\text { Male (50\%); Female } \\
(50 \%)\end{array}$ \\
\hline
\end{tabular}

TWRB: total wildlife reserve of Bontioli (moderate use intensity); CAD: communal area of Dano (high use intensity); GRN: game ranch of Nazinga (low use intensity)

Table 3

Use values of the ten most used species in the three land use intensity levels

\begin{tabular}{|llllll|}
\hline Species & \multicolumn{3}{l}{ Use value } & & \\
& TWRB & CAD & GRN & Means & Sd \\
\cline { 2 - 6 } & 2.88 & 4.29 & 4.16 & 3.78 & 0,78 \\
\hline Vitellaria paradoxa C.F. Gaertn. & 2.17 & 2.92 & 1.97 & 2.35 & 0,5 \\
\hline Parkia biglobosa (Jacq.) R. Br. ex G. Don f. & 2.40 & 2.78 & 1.57 & 2.25 & 0,62 \\
\hline Diospyros mespiliformis Hochst. ex A. DC. & 1.64 & 2.39 & 1.05 & 1.69 & 0,67 \\
\hline Adansonia digitata L & 1.50 & 2.25 & 1.00 & 1.58 & 0,63 \\
\hline Lannea microcarpa Engl. \& K. Krause & 2.08 & 2.42 & 0.09 & 1.53 & 1,26 \\
\hline Faidherbia albida (Delile) A. Chev. & 1.11 & 1.46 & 1.94 & 1.50 & 0,42 \\
\hline Khaya senegalensis (Desv.) A. Juss. & 1.24 & 1.03 & 1.74 & 1.34 & 0,36 \\
\hline Afzelia africana Sm. ex Pers. & 1.57 & 1.67 & 0.58 & 1.27 & 0,6 \\
\hline Ficus sycomorus L. & 1.28 & 1.31 & 1.12 & 1.24 & 0,1 \\
\hline Pterocarpus erinaceus Poir. & & & & & \\
\hline $\begin{array}{l}\text { TWRB: total wildlife reserve of Bontioli (moderate use intensity); CAD: communal area of Dano (high } \\
\text { use intensity); GRN: game ranch of Nazinga (low use intensity); Sd: standard deviations }\end{array}$
\end{tabular}




\section{Factors Influencing Populations' Knowledge Of Ecosystem Services}

With regard to the population's knowledge in the different land-use intensity categories (Table 4), the citation of the ten most used plant species varied significantly with the ES $(p<0,05)$, except for soil fertility, water purification and pest control services $(p>0.05)$. With regard to the sociocultural groups (Table 4), the relative frequency of citation of used plant species varied significantly with the different ES $(p<0,05)$ except for pest control service $(p>0.05)$.

In order to understand the effect of land use intensity by particular sociocultural groups, a differentiation of the sociocultural groups was made according to their living sites. From this subdivision, 6 groups emerged which were subjected in association with their uses to an HCPC hierarchy test (Fig. 5). These are: the groups of Kassena, GRN Mossi, TWRB Mossi, Pougouli, CAD Dagara and TWRB Dagara. The test discriminated four groups, that of the TWRB Mossi which is very different from the others, the Dagara group from the TWRB and the CAD; the Pougouli group in the CAD; and the Kassena and Mossi groups of the GRN. However, the Pougouli and the GRN resident groups are more similar.

The principal component analysis grouped the 15 services (initial variables) into 5 synthetic variables or principal components. The two first principal components are represented by the graph of the PCA ordination (Fig. 6). The first component (Axis 1) explains $45.56 \%$ of the total variation while the second component (axis 2 ) explains $28.27 \%$. Therefore, these two axes explaining $73.83 \%$ of the total variation were used to describe the link between sociocultural groups and ES. Axis 1 discriminated the natives of CAD and TWRB from the migrant (Mossi) and the riparians of GRN. According to this axis, the Mossi of TWRB make use of the 15 ecosystem services only to a small degree and GRN residents mainly use the craft service while the native of CAD and TWRB largely use the majority of services. Axis 2 discriminated the uses of the Dagara from those of the Pougouli. According to this axis 2, Dagara in TWRB and CAD utilize soil fertilization, erosion prevention and medicinal use services from plants. The Pougouli utilize food supply, religion, wind protection, shading and energy supply services from plants. The principal component analysis indicates that the exploitation of ES is a function of the level of land use intensity and the economic benefits that people derive from plant formations. Thus, the GRN populations who benefit from the financial incomes of tourism and participate in the management of the ranch utilize the craft services related to tourism. However, the natives of the TWRB who do not benefit financially from this reserve and the natives of the anthropogenically shaped CAD exploit the services of the plants that sustain the quality of the agricultural land and insure the primary needs of the rural populations. 
Table 4

Variation of citations of ecosystem services provided by the ten most used species across the three study sites and the sociocultural groups.

\begin{tabular}{|c|c|c|c|c|c|c|c|}
\hline \multirow[t]{2}{*}{ ES categories } & \multirow[t]{2}{*}{ ES } & \multicolumn{3}{|c|}{ Study sites } & \multicolumn{3}{|c|}{ Sociocultural groups } \\
\hline & & D.f & $\chi^{2}$ & P-value & D.f & $x^{2}$ & P-value \\
\hline Supporting & Soil fertility & 2 & 5.77 & 0.06 & 3 & 15.35 & 0.001537 \\
\hline \multirow[t]{3}{*}{ Cultural } & Tourism & 2 & 47.11 & $<0.0001$ & 3 & 50.25 & $<0.0001$ \\
\hline & Religion & 2 & 60.16 & $<0.0001$ & 3 & 101.25 & $<0.0001$ \\
\hline & Ceremonies & 2 & 36.61 & $<0.0001$ & 3 & 76.85 & $<0.0001$ \\
\hline \multirow[t]{5}{*}{ Regulating } & Water purification & 2 & 1.59 & 0.45 & 3 & 22.41 & $<0.0001$ \\
\hline & Shading & 2 & 50.37 & $<0.0001$ & 3 & 51.98 & $<0.0001$ \\
\hline & Wind protection & 2 & 42.20 & $<0.0001$ & 3 & 58.24 & $<0.0001$ \\
\hline & Pest control & 2 & 4.14 & 0.13 & 3 & 5.00 & 0.1716 \\
\hline & Erosion prevention & 2 & 33.33 & $<0.0001$ & 3 & 31.59 & $<0.0001$ \\
\hline \multirow[t]{6}{*}{ Provisioning } & Medicinal use & 2 & 126.51 & $<0.0001$ & 3 & 142.52 & $<0.0001$ \\
\hline & Building & 2 & 44.13 & $<0.0001$ & 3 & 52.04 & $<0.0001$ \\
\hline & Crafts & 2 & 61.24 & $<0.0001$ & 3 & 38.48 & $<0.0001$ \\
\hline & Energy supply & 2 & 14.38 & 0.0007 & 3 & 6.89 & $<0.0001$ \\
\hline & Fodder supply & 2 & 36.22 & $<0.0001$ & 3 & 24.11 & $<0.0001$ \\
\hline & Food supply & 2 & 61.18 & $<0.0001$ & 3 & 85.72 & $<0.0001$ \\
\hline
\end{tabular}

\section{Vulnerability Of The Most Used Species}

The vulnerability indices of the ten most used species in the study area varied from 2.28 to 2.85 (Fig. 7), indicating the pressures resulting from the exploitation of these species by local populations. Except for Faidherbia albida, Lannea microcarpa and Vitellaria paradoxa classified as moderately vulnerable species, the other seven species (Adansonia digitata, Afzelia africana, Diospyros mespiliformis, Ficus sycomorus, Khaya senegalensis, Parkia biglobosa and Pterocarpus erinaceus) were highly vulnerable with IV $>2.5$. 
The relative frequency of local perception on the availability of species revealed that more than $60.10 \%$ of local populations consider all used species as abundant to very abundant. Among the most used species, Vitellaria paradoxa was the most cited as very abundant species (34.76\%). In contrast, Adansonia digitata was the most cited as very rare species (58.05\%) in the study area followed by Faidherbia albida (55.65\%) which is only found in agrosystem.

Concerning the dynamics of the species, $40.07 \%$ of the respondents admitted a regression of the species they use. Among the most used species, $V$. paradoxa is the species with the highest dynamics $(50 \%$ increase) while $A$. digitata is the one with the lowest dynamics ( $52.3 \%$ decrease).

Table 6

Relative frequency of local population's perception on availability and dynamics of the ten most used species

\begin{tabular}{|lllllll|}
\hline Species & \multicolumn{3}{l}{ Species availability (\%) } & \multicolumn{4}{l|}{ Species dynamics (\%) } \\
\cline { 2 - 5 } & $\begin{array}{l}\text { Very } \\
\text { abundant }\end{array}$ & Abundant & Rare & Decrease & Constancy & Increase \\
\hline Adansonia digitata & 12.07 & 29.88 & 58.05 & 52.30 & 19.54 & 28.16 \\
\hline Afzelia africana & 7.65 & 54.1 & 38.25 & 40.44 & 17.49 & 42.08 \\
\hline $\begin{array}{l}\text { Diospyros } \\
\text { mespiliformis }\end{array}$ & 10.46 & 66.28 & 23.26 & 38.15 & 23.12 & 38.73 \\
\hline Faidherbia albida & 5.64 & 38.71 & 55.65 & 45.60 & 24.80 & 29.60 \\
\hline Ficus sycomorus & 12.23 & 54.68 & 33.09 & 38.85 & 21.58 & 39.57 \\
\hline Khaya senegalensis & 21.76 & 48.83 & 29.41 & 45.61 & 13.45 & 40.94 \\
\hline Lannea microcarpa & 13.83 & 60.64 & 25.53 & 34.57 & 23.94 & 40.96 \\
\hline Parkia biglobosa & 19.61 & 51.96 & 29.9 & 41.35 & 16.83 & 41.83 \\
\hline Pterocarpus erinaceus & 11.66 & 55.83 & 32.51 & 43.90 & 21.95 & 34.15 \\
\hline Vitellaria paradoxa & 34.76 & 46.36 & 18.88 & 29.49 & 20.51 & 50.00 \\
\hline
\end{tabular}

\section{Local population's perceptions on the conservation of Sudanian savanna ecosystems}

Regarding the responsible factors for vegetation degradation, local populations agree that fire (P-value $=$ $0.08)$, cutting of fresh wood ( $P$-value $=0.60)$ and clearing for extension of the cultivated areas $(P$-value $=$ 0.59 ) were most important. There were no significant differences among socio-cultural groups about the above mentioned causes (Table 7). 
Generally, the solutions preferred by different sociocultural groups for ecosystem conservation are similar except for fire prohibition ( $P$-value $=0.02^{*}$ ). These solutions relate to a participation of local populations in the management of plant resources. Local populations ranked, by order of preference, five solutions for ecosystem conservation and four motivations for participating in sustainable management of ecosystems. For the suggested solutions, they ranked first "raising the awareness of local populations on the danger from degradation of natural resources" (Table 7) followed by "prohibition of fires by forest authorities" (P-value $\left.=0.02^{\star}\right)$.

The motivations of sociocultural groups for the sustainable management of plant resources are preferentially linked to their overall well-being through the continuity of the provision of ecosystem services which will be ensured by the long-term presence of the species (P-value $=0.39)$, then follows the consideration of basic social needs such as health, basic education, drinking water and electricity provision by local authorities" through the development of the village (P-value $\left.=0.002^{\star \star}\right)$.

Table 7

Comparison test of Kruskal-Wallis about factors, suggested solutions and motivation for ecosystem conservation according to sociocultural groups

\begin{tabular}{|c|c|c|c|c|c|}
\hline Questions & Perception item & Order of preference & $\chi^{2}$ & D.f & P-value \\
\hline \multirow[t]{7}{*}{ Factors } & Fire & 1 & 8.38 & 4 & 0.08 \\
\hline & Wood cutting & 2 & 2.75 & 4 & 0.60 \\
\hline & Clearing & 3 & 2.78 & 4 & 0.59 \\
\hline & Demographic increase & 4 & 14.37 & 4 & $0.006^{\star}$ \\
\hline & Pasture & 5 & 15.81 & 4 & $0.002^{\star}$ \\
\hline & Climate change & 6 & 9.22 & 4 & 0.06 \\
\hline & Forest management & 7 & 33.38 & 4 & $\nabla 0.0001^{* * *}$ \\
\hline \multirow[t]{5}{*}{ Solution } & Awareness of degradation & 1 & 5.32 & 4 & 0.25 \\
\hline & Fire prohibition & 2 & 11.37 & 4 & $0.02 *$ \\
\hline & Inspection and Reforestation & 3 & 9.58 & 4 & 0.05 \\
\hline & Inclusive management & 4 & 7.00 & 4 & 0.14 \\
\hline & Subvention from the government & 5 & 7.45 & 4 & 0.11 \\
\hline \multirow[t]{4}{*}{ Motivation } & Vegetation perennity & 1 & 4.10 & 4 & 0.39 \\
\hline & Village development & 2 & 16.68 & 4 & $0.002^{\star}$ \\
\hline & Diversification of income & 3 & 2.73 & 4 & 0.60 \\
\hline & Obtaining a job & 4 & 24.29 & 4 & $\nabla 0.0001 * * *$ \\
\hline
\end{tabular}




\section{Discussion}

\section{Diversity of used plant species and ecosystem services}

163 plant species were cited by local populations as those providing them with different ecosystem services from Sudanian savannas. When considering the total number of species (1410) found by Zizka et al. [10] in the South Sudanian phytogeographic sector of Burkina Faso, only $11.6 \%$ of the potential flora of the study area are used by local populations. Each ES involves a great diversity of plant species: at least 60 species are used for10 ES. This diversity of used resources makes it possible to overcome the problem of insufficient plant resources for a given service and could be exploited for the substitution of the most threatened species by those having a good abundance in vegetation [23]. However, some specific ES involve specific species with specific property and characteristic. For example, the building service is provided by stable and resistant species such as Khaya senegalensis (Desv.) A. Juss., Anogeissus leiocarpa, Burkea africana Hook. and Pterocarpus erinaceus Poir. [5]. In the study area, the most cited service was food supply followed by medicinal services. The importance of food supply and medicinal use ES have been reported from investigations in the west [37], south [38] and north [39] of Burkina Faso and Côte d'Ivoire [40].

The relatively high percentage of use of fruits and leaves could be explained by their importance in various services such as food, fodder supply and medicinal use. The high frequency of fruits citation (70\%) for food supply shows the importance of fruit in the diet of local populations. In addition, plant species used for food supply were also used for medicinal service. In fact, Sourabié et al. [41] reported anti-diarrheal property of the fruit's pulp of Adansonia digitata and that Parkia biglobosa seeds lower hypertension.

The highest relative frequency $(31 \%)$ of citations of the whole plant shows that local people are aware of the importance of vegetation and trees for their well-being, as the services they associate with the whole plant are regulatory, cultural and supporting services. These services are not destructive for plants and ecosystems but are rather conservative. This demonstrates local populations being committed to the conservation of their environment which constitutes their living space.

The 10 species with the highest use values were all woody species, and the shea tree (Vitellaria paradoxa) is the species with the highest use value (3.775). Vitellaria paradoxa is a very popular species. In addition to its use in almost all services (14 of 15), it has a real use (UV) far more important than that of others species and a high socio-economic value. This oleaginous species represents the fourth exportation product of Burkina Faso after gold, cotton and livestock. Its high importance for populations was confirmed by other ethnobotanical studies $[6,24,37,38,42,43]$. Almonds and fruits of Vitellaria paradoxa, fruit pulp and seeds of Parkia biglobosa, and fruit pulp and leaves of Adansonia digitata are highly appreciated as non-timber forest products which provide income through their trade [44]. Shea butter (from Vitellaria paradoxa) and the african mustard, also named soumbala, (from Parkia biglobosa) are transformed products with strong chains of added values $[45,46]$. Diospyros mespiliformis and 
Lannea microcarpa have very appreciated edible fruits and medicinal uses. Faidherbia albida is a fodder woody species most appreciated by livestock breeders because it bears leaves and pods during the dry season when most of the woody species suffer from the harsh climate [39]. Faidherbia albida also has a high value of fertilizing cultivated or fallow soils [33] and is seen as a mystic plant by the Mossi [47]. Khaya senegalensis, Ficus sycomorus, Afzelia africana and Pterocarpus erinaceus are also fodder species with medicinal and cultural value [20,47, 48]. Anti-malarial virtues of Afzelia africana, Khaya senegalensis, Ficus sycomorus, Parkia biglobosa and Pterocarpus erinaceus are mentioned from Ghana [49]. The medicinal uses of the most cited species from our study area are also mentioned from other regions of Burkina Faso [50, 41, 39].

With regard to high use value and the high demand for the products of most cited species, they constitute key species for local populations according to the definition by Clark and Sunderland [51]. However, when the value of a NTFP and the intensity of its use are extremely high, it is very likely that the resource is being overexploited, causing it to become locally extinct [51]. Gaisberger et al. [52] showed that overexploitation of species has emerged as the most important short-term threat. Overexploitation is the single most important threat for Parkia biglobosa (41.2\%) and Vitellaria paradoxa (41.1\%), and is only slightly exceeded by climate change in the case of Adansonia digitata (38.0\%).

\section{Factors influencing the knowledge of ecosystem services}

The three level of land use intensities of this study design are motivated by the economic benefit that local communities derive from them. The populations of the CAD live mainly from agriculture as well as those of the TWRB. The populations living near the TWRB who do not benefit from economic benefits of protected areas in the same way as those of GRN engage in illegal activities such as farming, pasture and wood cutting in the protected area [14]. In fact, at least $18 \%$ of TWRB has been cleared [53] by local populations to install their fields. Forest administration has great difficulties to prevent neighboring villagers from using of the resources in protected zones that they highly depend on $[7,13]$ as long as no incentives are offered. In contrast, at the same time, the local populations living near GRN are employed with the forest officers to ensure functioning of this tourist attraction. Correspondingly, if the populations living near TWRB increase their income by illegal activities which contribute to forest destruction, the populations living near GRN vary their income by participating in forest management. Likewise, hunting in the village hunting zone (around GRN) and fishing in different water points of the ranch provide populations with additional income. Therefore, providing biodiversity conservation actors with diversified sources of income has economic importance to local communities [15,54]. The management of natural resources involving local communities contributes to better security of biodiversity through sustainable participatory management [55].

As for the sociocultural groups, the Pougouli had more knowledge in food supply, religion, wind protection, shading and energy supply ES. In fact, the Pougouli knowledge in religion services expresses the animist cult influence of Pougouli. According to the national statistics of population, the populations of the Southwest region have $64.9 \%$ of animists [56]. The high quote of religion ES is a means to preserve the surrounding vegetation and ecosystem. Religion are excellent channels for transmitting local 
knowledge through initiations (which are traditional and spiritual instructions) and which participate in the education of the youngest in the preservation of the environmental values. For the animist communities such as Pougouli, forests are the habitats of venerate spirits $[47,48]$. The use of species in food supply, wind protection, shading and energy supply ES reflects the poverty of these populations who depend heavily on income from agriculture and small livestock. The Dagara had more knowledge about medicinal use, soil fertilization and anti-erosion services. Their good knowledge about species providing medicinal services may be explained by the preservation of their ancestral knowledge transmitted from generation to generation and resulting of experimentation $[57,3,16]$. The Dagara are an introvert sociocultural group little open to exterior influence and quite attached to their local environment. Dagara knowledge is also orientated to performing farming. They are essentially farmers and do not hesitate to transgress protected areas to install their farming [14]. The population of Nazinga gives the little importance to medicinal services due to the fact that they live nearby a health center, leading to a loss of local knowledge about medicinal plants. Local populations are subjected to increasing social (demographic and economic) and environmental pressures which have an impact on plant knowledge and have mostly resulted in the loss of knowledge [24,58]. Indeed, species distribution, their availability over time and their uses by local populations constitute three factors which conditioned the knowledge and use of species [59, 5, 39]. However, TWRB Mossi had no specific knowledge about ES provided by Sudanian savanna species. This shows that they are not integrated into native communities of their specific village neighborhoods. In CAD, the migrant communities are located outside the villages which constitutes an obstacle for passing on and sharing inter-community knowledge. In addition, the lack of specific knowledge about Sudanian vegetation in Mossi migrants of TWRB could be related to the fact of having immigrated from the Sudano-Sahelian zone where the species composition is different. The ethnobotanical knowledge varies across sociocultural groups because of cultural differences and social habits $[4,60]$.

On the contrary, Kassena and GRN Mossi sociocultural groups possessed similar knowledge and had more knowledge in craft, energy and touristic services. This demonstrates that Mossi migrants of GRN are well integrated and adapted to the native way of life. Thus, the migrants replace species which they originally used by species which serve the same purpose among the natives. Thus, plant use strongly depends on social factors and differs considerably between different sociocultural groups and locations $[3,6]$. But the continued traditional use of species by migrant communities can be influenced more strongly by the environment than by cultural heritage [61].

\section{Vulnerability Of The Ten Most Used Species}

Except for Faidherbia albida, Lannea microcarpa and Vitellaria paradoxa classified as moderately vulnerable species ( 2 \IV $\leq 2.5$ ), the seven other species (Adansonia digitata, Afzelia africana, Diospyros mespiliformis, Ficus sycomorus, Khaya senegalensis, Parkia biglobosa and Pterocarpus erinaceus) were highly vulnerable with IV $>2.5$. The increasing purpose of use, the plant organs used and the preference (the high use value) that populations have for these species act to increase their vulnerability. In the same 
phytogeographic area (in the western region of Burkina Faso), Traoré et al. [20] classified Vitellaria paradoxa, Lannea microcarpa, Faidherbia albida and Afzelia africana as weakly vulnerable. However, the state of vulnerability of Adansonia digitata, Afzelia africana, Khaya senegalensis, Parkia biglobosa and Pterocarpus erinaceus is confirmed by Thiombiano et al. [62] who classify them among the threatened species of the southern Sudanian zone. According to these authors, Diospyros mespiliformis would be more threatened in the northern Sudanian zone. In the sub-Sahelian zone, Ouedraogo et al. [39] confirm the vulnerability of Adansonia digitata, Diospyros mespiliformis, Faidherbia albida, Khaya senegalensis, Lannea microcarpa, Parkia biglobosa, Pterocarpus erinaceus and Vitellaria paradoxa. All these 10 species are also considered endangered by the local populations of northern Benin [63]. Nevertheless, for the vast majority of plant species in Burkina Faso insufficient data are available for a full IUCN assessment [11, 27]. Globally and according to the IUCN red list [64], the conservation status of Pterocarpus erinaceus has been decreasing and has become EN (endangered), indicating a very high risk of extinction. Afzelia africana, Khaya senegalensis and Vitellaria paradoxa conservation status are VU (vulnerable), indicating a high risk of extinction. Parkia biglobosa, Diospyros mespiliformis, Adansonia digitata, Lannea microcarpa, Faidherbia albida and Ficus sycomorus status are Least Concern (LC) species that do not qualify for one of the above. Although these species have different levels of vulnerability in other regions of Burkina Faso due to the uses of local populations, they are of great interest to the populations of our study sites. It would then be appropriate to think about their sustainable management through rational use motivated by the perceptions of local populations.

\section{Local perceptions about availability and dynamics of the species most used}

Perceptions of local populations on the availability and dynamics of species and especially of the ten most used species follow the same trend. The species used are considered abundant by the local populations thus justifying their use. Also the dynamics of the species are generally conceived as static because the proportion of opinions in favor of a decrease of the species is approximately equal to that of the opinions in favor of their increase. Indeed, local populations state that Vitellaria paradoxa was the most abundant species and has an increase whereas Adansonia digitata was very rare and has a decrease. Traore et al. [20] found that, in the South-west of the country, the socio-economic importance of the species influences the Senufo's assessment of their availability. Thus, less variation in the availability of important species is perceived. The socio-economic importance, availability and dynamics of species define the management of traditional agroforestry systems. According to Assogbadjo et al. [21], the species perceived by local communities as threatened are integrated into traditional agroforestry systems. However, the populations admit the general degradation of the ecosystems and give their perceptions of this phenomenon.

\section{Local Perceptions On The Conservation Of Sudanian Savanna Ecosystems}


According to local populations, fire, deforestation and clearing constitute the three main causes of Sudanian vegetation degradation. Local populations use fire as a tool for hunting, clearing of village surroundings and fields preparation [60]. The deforestation by wood cutting corresponds to the demand for energy, craft and construction services. The clearing of natural formations is practiced for installation of new agricultural land and for extension of pre-existing agricultural land. Local populations are conscious of the causes of the degradation of plant resources being essentially anthropogenic. They are the principal actors of these pressures which correspond to the increasing need of growing populations $[14,7,13]$. Although the development of agriculture makes it possible to free oneself from dependence on wild food, the expansion of agricultural lands strongly contributes to ecosystems degradation [65]. On the local level, land use changes effectively have a negative impact on biodiversity due to habitat loss or fragmentation [20].

Raising the awareness of local populations in the face of degrading natural resources is the first solution suggested unanimously by the communities. Given that climate change is not well perceived at the local scale, awareness raising may contribute to reducing anthropogenic pressure (fire, wood logging). Local population's awakening of awareness as to the vulnerability of plant resources used daily and their implication to natural resources management in collaboration with forest authorities are steps that would ensure sustainable conservation of plants. The success of biodiversity conservation efforts often depends on local populations, especially when these communities are the key players of ecosystems management [66]. In fact, the high biodiversity existing in native territories around the world is the result of traditional knowledge and management practices [16]. The fair collaboration of local populations in the conservation of plant resources could be achieved, for example, by meeting certain basic needs such as the creation of water reservoirs and the construction of health centers and schools.

\section{Conclusion}

This study has highlighted the importance of ES of Sudanian savannas and the importance of the longterm preservation of numerous plant species. Our work shows that local populations know their environment well, and that they are aware of the causes of degradation of plant resources. Therefore, local people should be involved in programs and projects addressing sustainable management and conservation of Sudanian savanna ecosystems. The behavioral change can be achieved by awarenessraising and education. Local populations' education needs information on best management strategies and the promotion of local multipurpose species domestication and regeneration. Also species with low utilization value should be protected for conserving biological diversity because species being less important today could be sought for in the future to replace others having become rare in the meantime.

However, in face of local population vulnerability and their strong dependence on natural resources, it is often difficult to consolidate conservation and rational and sustainable use of biodiversity. In order to achieve effective awareness raising among local populations for the sustainable management of plant resources, it would be necessary to offer them solutions and motivations adapted to their perceptions and their consents. This approach will enable full collaboration of the sociocultural communities. 


\section{Abbreviations}

ES

ecosystem services

TWRB

total wildlife reserve of Bontioli (moderate use intensity);

CAD

communal area of Dano (high use intensity);

GRN

game ranch of Nazinga (low use intensity

\section{Declarations}

\section{Ethics approval and consent to participate}

Individual consent to participate in the study was obtained prior to the administration of the questionnaire. Only people that consented to participate in the study were considered.

\section{Availability of data and materials}

The datasets used and/or analyzed in the current study are available from the corresponding author on reasonable request.

\section{Consent for publication}

Not applicable

\section{Competing interests}

The authors declare that they have no competing interests.

\section{Funding}

This research was supported by the BMBF (German Federal Ministry of Education and Research) through the program WASCAL (West African Science Service Center on Climate Change and Adapted Land Use, www.wascal.org).

\section{Authors' contributions}

AN and DG conceived the work with advices from AT. AN collected the data. AN processed the data and performed the statistical analyses. AN and DG drafted the manuscript with contribution of AO, SP and AT. AT supervised the work. All authors read and approved the final manuscript.

\section{Acknowledgements}


The authors thank the West Africa Science Service Center on Climate Change and Adapted Land Use (WASCAL) program funded by the German Federal Ministry for Education and Research (BMBF) and the National Center for Information, Scholar and Professional Orientation, and Scholarship (CIOSPB) for the financial support. Many thanks to the National Office of Protected Areas (OFINAP) to have given us access to protected areas, and especially to local populations of communal area of Dano (CAD), total wildlife reserve of Bontioli (TWRB) and game ranch of Nazinga (GRN) for their cooperation and the sharing of their knowledge.

\section{References}

1. Millennium Ecosystem Assessment (MEA). Ecosystem Wealth and Human Well-Being, Island Press. 2005.

2. UICN France. Panorama des services écologiques fournis par les milieux naturels en France. 2012 ; volume 1 : contexte et enjeux. Paris, France.

3. Bognoumou F., Savadogo P., Thiombiano A., Boussim J. I., Oden P. C. and Guinko S. Informants based ethnobotany and utility evaluation of five combretaceae species: differentiation by socioculturality and geographical location. Forests, Trees and Livelihoods. 2011; Vol. 20, pp. 265282.

4. Sop T.K., Oldeland J., Schmiedel, U., and Thiombiano, A. Ethnobotanical knowledge and valuation of woody plants species: a comparative analysis of three sociocultural groups from the sub-Sahel of Burkina Faso. Environ Dev Sustain. 2012.

5. Ouédraogo, I., Nacoulma, B.M.I., Hahn, K., and Thiombiano, A. Assessing ecosystem services based on indigenous knowledge in south-eastern Burkina Faso (West Africa). International Journal of Biodiversity Science, Ecosystem Services and Management. 2014; 10 (4), 313-321.

6. Zizka, A., Thiombiano, A., Dressler, S., Nacoulma, B.I., Ouédraogo, A., Ouédraogo, I., Ouédraogo, O., Zizka, G., Hahn, K., and Schmidt, M. Traditional plant use in Burkina Faso (West Africa): A nationalscale analysis with focus on traditional medicine. Journal of Ethnobiology and Ethnomedicine. 2015; 11 (1).

7. Belem B, Nacoulma BMI, Gbangou R, Kambou S, Hansen HH, Gausset Q, Lund S, Raebild A, Lompo D, Ouedraogo M, Theilade I, Boussim IJ. Use of non wood forest products by local people bordering the “Parc National Kaboré Tambi”, Burkina Faso. J Transdiscipl Environ Stud. 2007;6(1):1-21.

8. Ngom D., Charahabil M. M., Sarr O., Bakhoum A. and Akpo L. E. Perceptions communautaires sur les services écosystémiques d'approvisionnement fournis par le peuplement ligneux de la Réserve de Biosphère du Ferlo (Sénégal). VertigO [Online]. 2014 ; Volume 14 Numéro 2, consulted the December $14^{\text {th }}, 2020$. URL: http://journals.openedition.org/vertigo/15188; DOI: 10.4000/vertigo.15188

9. Fontès J, Guinko S. Carte de la végétation et de l'occupation du sol du Burkina Faso. Notice explicative. Ministère de la Coopération française, projet Campus, Toulouse. 1995 ; p. 68.

10. Zizka A., Thiombiano A., Dressler S., Nacoulma B. M. I., Ouédraogo A., Ouédraogo I., Ouédraogo O., Zizka G., Hahn K., Schmidt M. The vascular plant diversity of Burkina Faso (West Africa) - a 
quantitative analysis and implications for conservation. Candollea. 2015; 70(1). Pp 9-20.

11. Schmidt M., Zizka A., Traoré S., Ataholo M., Chatelain C., Daget P., Dressler S., Hahn K., Kirchmair I, Krohmer J., Mbayngone E.,. Müller J. V., Nacoulma B., Ouédraogo A., Ouédraogo O., Sambaré O., Schumann K., Wieringa J. J., Zizka G. and Thiombiano A. Diversity, distribution and preliminary conservation status of the flora of Burkina Faso. Phytotaxa 304.215 pp.; 30 cm. 18 April 2017. ISBN 978-1-77670-122-3 (paperback). ISBN 978-1-77670-123-0 (Online edition)

12. Institut National de la Statistique et de la Demographie (INSD). Résultats préliminaires du cinquième recensement général de la population et de l’habitat du Burkina Faso. 2020.

13. Gnoumou , Rusu E., Adouabou B., Thiombiano A., 2016. Spatial and temporal dynamics of the vegetation of Comoé-léraba reserve and its surrounding lands (Burkina Faso, West Africa). PESD. 2016; Vol. 10, No. 1, DOI 10.1515/pesd-2016-0002

14. Dimobe, K., Ouédraogo, A., Soma, S., Goetze, D., Porembski, S., and Thiombiano, A. Identification of driving factors of land degradation and deforestation in the Wildlife Reserve of Bontioli (Burkina Faso, West Africa). Global Ecology and Conservation. 2015;4: 559-571.

15. Dimobe, K., Goetze, D., Ouédraogo, A., Forkuor, G., Wala, K., Porembski, S., and Thiombiano, A. SpatioTemporal Dynamics in Land Use and Habitat Fragmentation within a Protected Area Dedicated to Tourism in a Sudanian Savanna of West Africa. Journal of Landscape Ecology(Czech Republic). 2017; 10 (1), 75-95.

16. Diegues A. C. The role of ethnoscience in the build-up of ethnoconservation as a new approach to nature conservation in the tropics. (case of Brazil). Revue d'ethnoécologie. 2014;6.

17. OCDE (Organization of Cooperation and Economic Development). Climate Change and Agriculture: Impacts, Adaptation, Mitigation and Options for the OECD [COM/TAD/CA/ENV/EPOC. 2009;13]; http://olisweb.oecd.org/, consulted the 26/09/2019.

18. Bambara, D.; Bilgo, A., Hien, E., Masse, D., Thiombiano, A.;, and Hien, V. Influencedes composts de dechets urbains sur les rendements du Sorgho en zone soudano-sahélienne du Burkina Faso. Ivoir. Sci. Technol. 2014; 24: 148-171.

19. Holou R.A.Y., Sinsin B. Embroussaillements des pâturages artificiels et naturels exploités par les bovins en zone guinéennes au Bénin. Ann. Sci. Agron. Bénin. 2002; 3 (1) 40-66.

20. Traore, L., Ouedraogo, I., Ouedraogo, A., and Thiombiano, A. Perceptions, usages et vulnérabilité des ressources végétales ligneuses dans le Sud-Ouest du Burkina Faso. International Journal of Biological and Chemical Sciences. 2011; 5 (1), 258-278.

21. Assogbadjo, A. E., Glèlè Kakaï, R., Vodouhê, F. G., Djagoun, C. A. M. S., Codjia, J. T. C., and Sinsin, B. Biodiversity and socioeconomic factors supporting farmers' choice of wild edible trees in the agroforestry systems of Benin (West Africa). Forest Policy and Economics. 2012;14:41-49.

22. Kaboré S. A., Hien M., Ouédraogo D., Diallo T. R. E., Hahn K. and Nacro B. H. Use of Ecosystem Services of Sarcocephalus latifolius (Sm.) E.A.Bruce and Induced Effect of Human Pressure on the Species in the Southwestern Region of Burkina Faso. Ethnobotany Research \& Applications.2014; 12 : 561-570. 
23. Kaboré S. A., Schumann K., Hien M., Lykke A. M., Hahn K. and Nacro B. H. Stratégies d'adaptation à la réduction des services écosystémiques: cas des Potentialités de substitution de trois espèces forestières dans le Sud-Ouest du Burkina Faso. Int. J. Biol. Chem. Sci. 2015 ; 9(3): 1194-1208.

24. Tiétiambou, F.R.S., Lykke, A.M., Korbéogo, G., Thiombiano, A., and Ouédraogo, A. Perceptions et savoirs locaux sur les espèces oléagineuses locales dans le Kénédougou, Burkina Faso. Bois et Forets des Tropiques. 2016; 327 (327), 39-50.

25. Dimobe K, Tondoh JE, Weber JC, Bayala J, Oue'draogo K, Greenough K. Farmers' preferred tree species and their potential carbon stocks in southern Burkina Faso: Implications for biocarbon initiatives. PLoS ONE. 2018; 13(12): e0199488. https://doi.org/10.1371/journal.pone.0199488.

26. Stein K, Stenchly K, Coulibaly D, et al. Impact of human disturbance on bee pollinator communities in savanna and agricultural sites in Burkina Faso, West Africa. Ecol Evol. 2018; 8:6827-6838. https://doi.org/10.1002/ece3.4197

27. Nacoulma B.M. I., Ouédraogo I., Ouédraogo O., Dimobe K. And Thiombiano A. Phytodiversity of Burkina Faso. Pullaiah T (Ed). Global Biodiversity. 2019; Volume 3: Selected Countries in Africa. Apple Academic Press Inc. ISBN 978-0-42946-980-0

28. Houéhanou D.T., Assogbadjo A. E., Chadare F. J., Zanvo S. \& Sinsin B. Approches méthodologiques synthétisées des études d'ethnobotanique quantitative en milieu tropical. Annales des Sciences Agronomiques. 2016 ; 20 - spécial Projet Undesert-UE : ISSN 1659-5009. Pp 187-205

29. Albuquerque U. P., Ramos M. A., Lucena R. F. P. and Alencar N. L. Methods and Techniques Used to Collect Ethnobiological Data. Springer Protocols Handbooks. 2014; DOI 10.1007/978-1-4614-86367_2.

30. Berhaut J. Flore du Sénégal. Edition Clairafrique, Dakar. 1967 : 485p.

31. LeBourgeois T. and Merlier H. Advantrop. Les adventices d’Afrique soudano-sahélienne. Montpellier, France, CIRAD-CA éditeurs. 1995 : 640 p.

32. Poilecot P. Les Poaceae du Niger. Description - Illustration - Ecologie - Utilisations. Boissiera. 1999 ; 56, Genève, Suisse. ISBN CIRAD 2-87614-342-9. 766p.

33. Arbonnier M. Arbres, arbustes et lianes d'Afrique de l'Ouest. Quae. 2019: P 776.

34. Camou-Guerrero A., Reyes-García V., Martínez-Ramos M., Casas A. Knowledge and Use Value of Plant Species in a Rarámuri Community: A Gender Perspective for Conservation. Human Ecology. 2008; 36: 259-272.

35. Betti JL. Vulnérabilité des plantes utilisées comme antipaludiques dans l'arrondissement de Mintom au sud de la réserve de Biosphère du Dja (Cameroun). Syst Geogr Plant. $2001 ; 71: 661-78$.

36. R Core Team. R: A language and environment for statistical computing. R Foundation for Statistical Computing, Vienna, Austria. 2019. URL https://www.R-project.org/.

37. Taita, P. Use of woody plants by locals in Mare aux Hippopotames Biosphere Reserve in western Burkina. Biodiversity and Conservation. 2003; 12, 1203-1217. 
38. Guigma, Y., Zerbo, P., and Millogo-rasolodimby, J. Utilisation des espèces spontanées dans trois villages contigus du Sud du Burkina Faso. TROPICULTURA. 2012; 30 (4): 230-235.

39. Ouédraogo P., Bationo B.A., Sanou J., Traoré S., Barry S., Dayamba S.D., Bayala J., Ouédraogo M., Soeters S., and Thiombiano A. Uses and vulnerability of ligneous species exploited by local population of northern Burkina Faso in their adaptation strategies to changing environments. Agriculture \& Food Security. 2017; 6: 15.

40. Vroh, B., Ouattara, D., and Kpangui, K. Disponibilité des espèces végétales spontanées à usage traditionnel dans la localité d'Agbaou, Centre-ouest de la Côte d'Ivoire. Journal of Applied Biosciences. 2014; 76 (1): 6386.

41. Sourabie T.S., Kinda D., Yaro B. And Nikiema J.B. Ethnobotanical Survey of Medicinal Plants Used By the Traditional Medical Healers in the Villages of Bérégadougou and Fabédougou (Cascades Region, Burkina Faso). IOSR Journal Of Pharmacy. 2013; 3(7): Pp 38-45. losrphr.Org

42. Bélem B, Smith Olsen C, Theilade I, Bellefontaine R, Guinko S, Mette Lykke A, et al. Identification des arbres hors forêt préférés des populations du Sanmatenga (Burkina Faso). Bois et Forêts des Tropiques.2008;298(4):53-64.

43. Cissé, M., Bationo, B.A., Traoré, S., and Boussim, I.J. Perception d'espèces agroforestières et de leurs services écosystémiques par trois groupes ethniques du bassin versant de Boura, zone soudanienne du Burkina Faso. Bois and Forets Des Tropiques. 2019 ; 338: 29.

44. Ouédraogo M., Ouédraogo D., Thiombiano T, Hien M. and Lykke A. M. Dépendance économique aux produits forestiers non ligneux : cas des ménages riverains des forêts de Boulon et de Koflandé, au Sud-Ouest du Burkina Faso. Journal of Agriculture and Environment for International Development JAEID. $2013 ; 107$ (1): 45 - 72

45. Badini Z., Kaboré M., Mheen-Sluijer J. and Vellema S. Chaînes de valeur de la filière karité au Burkina Faso. VC4PD Research Paper. 2011; No. 14.

46. Kronborg M. Improving livehoods in West Africa through a natural resources-The case of Parkia biglobosa and Soumbala. PhD thesis. Aarhus University. 2015.

47. Savadogo, S., SOP, T.K., and Thiombiano, A. Sacred and totemic plants among thirty two sociocultural groups in burkina faso: implications for biodiversity conservation. Annales des sciences agronomiques. 2017; 21 (1): 89-120.

48. Balima, L.H., Marie, B., Nacoulma, I., Rodrigue, M., and Ekué, M. Use patterns , use values and management of Afzelia africana Sm . in Burkina Faso: implications for species domestication and sustainable conservation. Journal of Ethnobiology and Ethnomedicine. 2018; 14 (23), 1-14.

49. Asase, A., Oteng-yeboah, A.A., Odamtten, G.T., and Simmonds, M.S.J. Ethnobotanical study of some Ghanaian anti-malarial plants. 2005; 99, 273-279.

50. Zerbo P., Millogo-Rasolodimby J., Nacoulma-Ouedraogo 0 and Van Damme P., 2007. Plantes médicinales et pratiques médicales au Burkina Faso : cas des Sanan. Bois Et Forêts Des Tropiques, $2011, N^{\circ} 307(1)$ 
51. Clark E.L. and Sunderland T.C. The key non timber Forest Products of central Africa: state of the Knowledge. Technical paper $N^{\circ} 122$. SD publication Series. Office of sustainable Development Bureau for Africa. USAID. 2004; 186p.

52. Gaisberger H, Kindt R, Loo J, Schmidt M, Bognounou F, Da SS, et al. Spatially explicit multi-threat assessment of food tree species in Burkina Faso: A fine-scale approach. PLoS ONE. 2017; 12 (9): e0184457. https://doi.org/10.1371/journal.pone.0184457

53. UICN/PACO. Évaluation de l'efficacité de la gestion des aires protégées : aires protégées du Burkina Faso. 2009.

54. Bouché, P., Lungren, C.G., \& Hien, B. Recensement aérien total de la faune dans l'Ecosystème naturel Po-Nazinga-Sissili (PONASI). Burkina Faso Programme CITES-MIKE, Rapport definitif. 2004.

55. Ouédraogo, M. Régulation de la dynamique des populations de buffles (Syncerus caffer Sparrman) et de Waterbucks (Kobus ellipsiprymnus Ogilby) et moyens de gestion à mettre en oeuvre pour préserver l'équilibre des communautés végétales dans le ranch de Nazinga (Burkina Faso). Unpublished doctoral dissertation, University of Gembloux. 2005.

56. Institut National de la Statistique et de la Demographie (INSD). Annuaire statistique 2017 de la région du Sud Ouest. 2018.

57. Lykke A. M. Local perceptions of vegetation change and priorities for conservation of woodysavanna vegetation in Senegal. Journal of Environmental Management. 2000; 59: 107-120. doi:10.1006/jema.2000.0336, available online at http://www.idealibrary.com.

58. Albuquerque U. P., Nascimento A. L. B., Soldati G. T., Feitosa I. S., Campos J. L. A., Hurrell J. A., Hanazaki N., Medeiros P. M., Silva R. R. V., Ludwinsky R H., Ferreira W. S. J. and Reyes-García V. Ten important questions/issues for ethnobotanical research. Acta Botanica Brasilica. 2019 ; 33(2). Belo Horizonte : http://dx.doi.org/10.1590/0102-33062018abb0331.

59. Ambé G.A. Les fruits sauvages comestibles des savanes guinéennes de Côte-d'Ivoire : état de la connaissance par une population locale, les Malinkés. Agron. Soc. Environ. 2001; 5(1): 43-58.

60. Koulibaly A., Traoré D. and Goetze D., 2010. Cacao and plant diversity. Thiombiano A and Kampmann D (eds). 2010: Atlas de la Biodiversité de l'Afrique de l'Ouest, Tome II: Burkina Faso. Ouagadougou and Frankfurt/Main.

61. Medeiros P. M., Soldati G.T., Alencar N. L., Vandebroek I., Pieroni A., Hanazaki N. and Albuquerque U. P. The Use of Medicinal Plants by Migrant People: Adaptation, Maintenance and Replacement. Review Article. Evidence-Based Complementary and Alternative Medicine. Hindawi Publishing Corporation. 2012. Article ID 807452, 11p. doi:10.1155/2012/807452.

62. Thiombiano A., Schmidt M., Da S., Hahn-Hadjali K., Zizka G. and Wittig R. Vascular plants: Flowering plants. Thiombiano A and Kampmann D (eds). 2010: Atlas de la Biodiversité de l'Afrique de l'Ouest, Tome II: Burkina Faso. Ouagadougou and Frankfurt/Main.

63. Agbani, P.O., Kafoutchoni, K.M., Salako, K.V., Gbedomon, R.C., Kégbé, A.M., Karen, H., and Sinsin, B. Traditional ecological knowledge-based assessment of threatened woody species and their potential 
substitutes in the Atakora mountain chain, a threatened hotspot of biodiversity in Northwestern

Benin, West Africa. Journal of Ethnobiology and Ethnomedicine. 2018; 14 (1), 1-19.

64. IUCN, 2020. Red list: https://www.iucnredlist.org. Page consulted on November 25, 2020

65. Mbayngone E. and Thiombiano A. Dégradation des aires protégées par l'exploitation des ressources végétales : cas de la réserve partielle de faune de Pama, Burkina Faso (Afrique de l'Ouest). 2011; 66 (3): 187-202.

66. Jones E.T. and Lynch K.A. Non timber forest products and biodiversity management in the Pacific Northwest. Forest Ecology and Management. 2007; 246: 29-37.

\section{Tables}

Table 5 is not available with this version

\section{Figures}

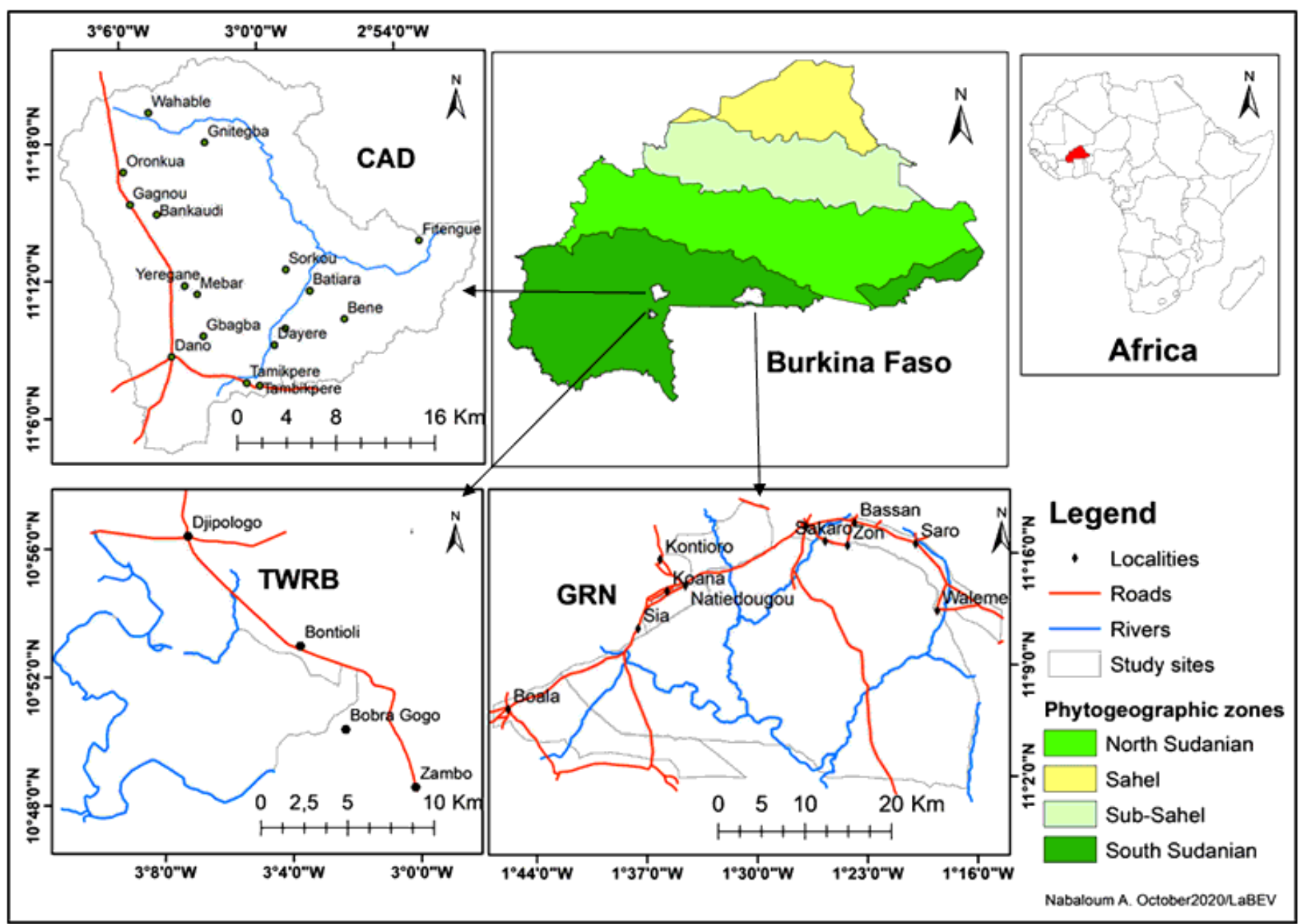

Figure 1 
Location of the study sites in Burkina Faso. TWRB: total wildlife reserve of Bontioli (moderate use intensity); CAD: communal area of Dano (high use intensity); GRN: game ranch of Nazinga (low use intensity);

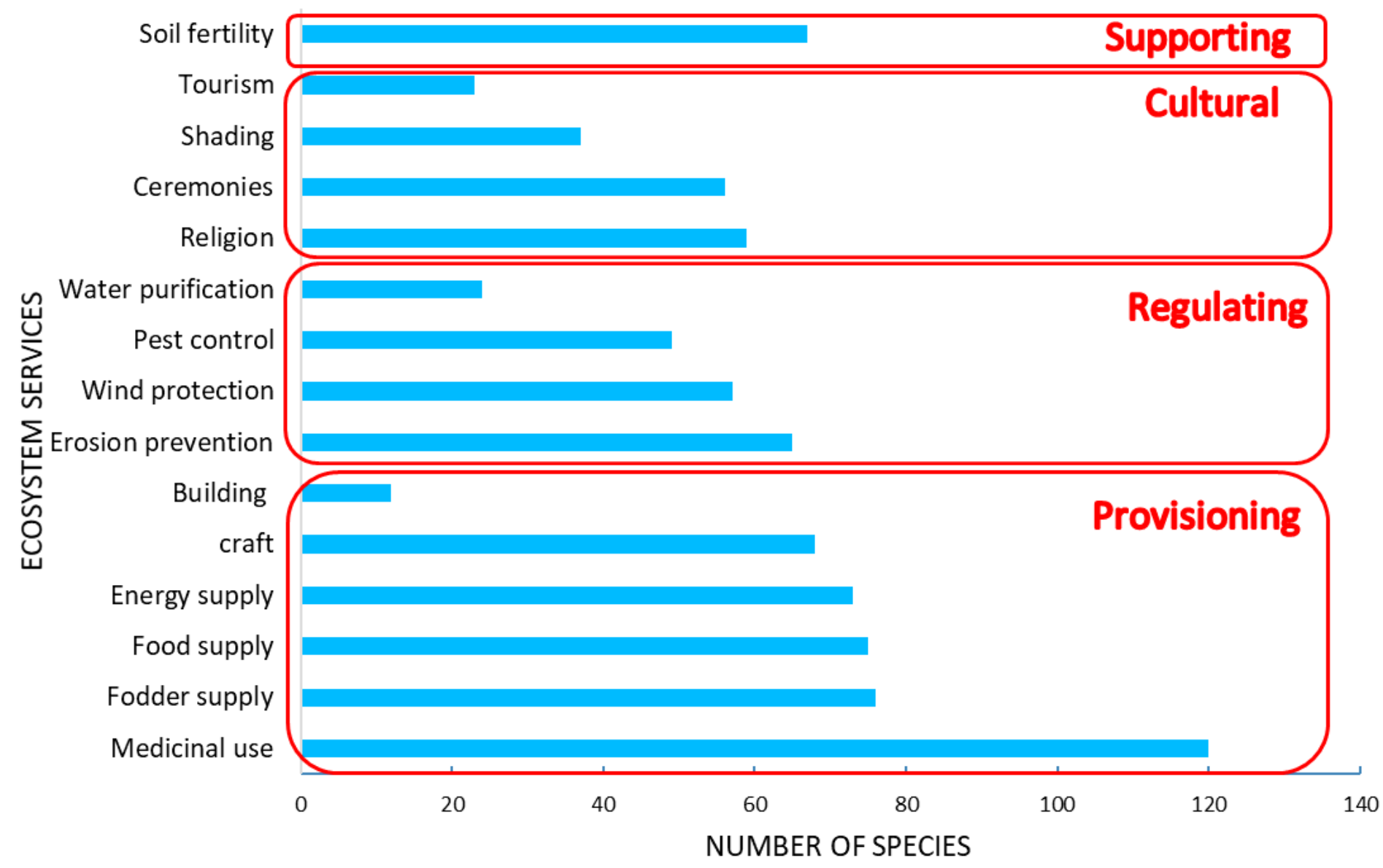

Figure 2

Distribution of species used into 15 Ecosystem Services 


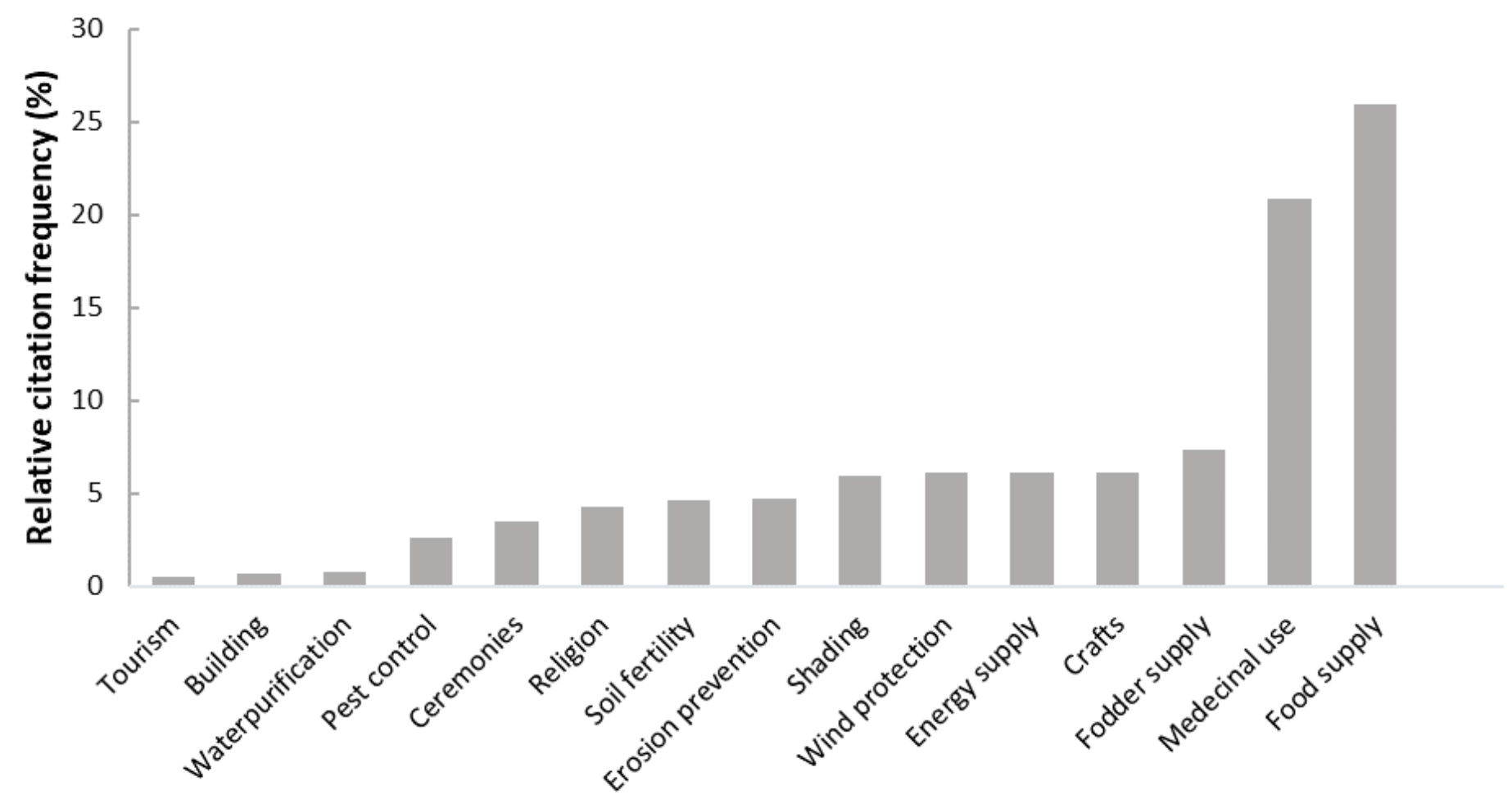

Ecosystem services

Figure 3

Relative frequency of citation of ecosystem services provided by species

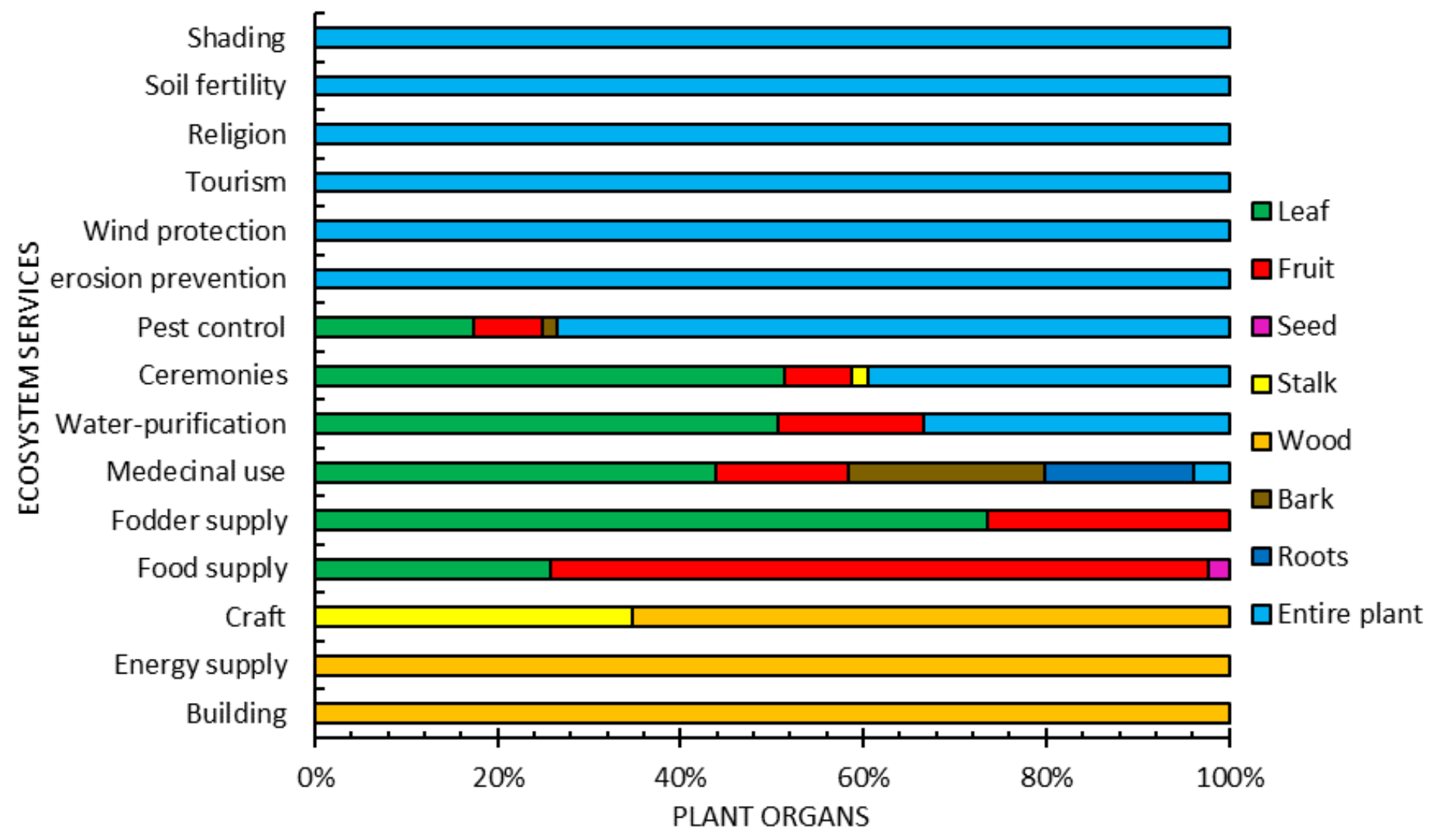


Percentage of plant parts used per ecosystem services

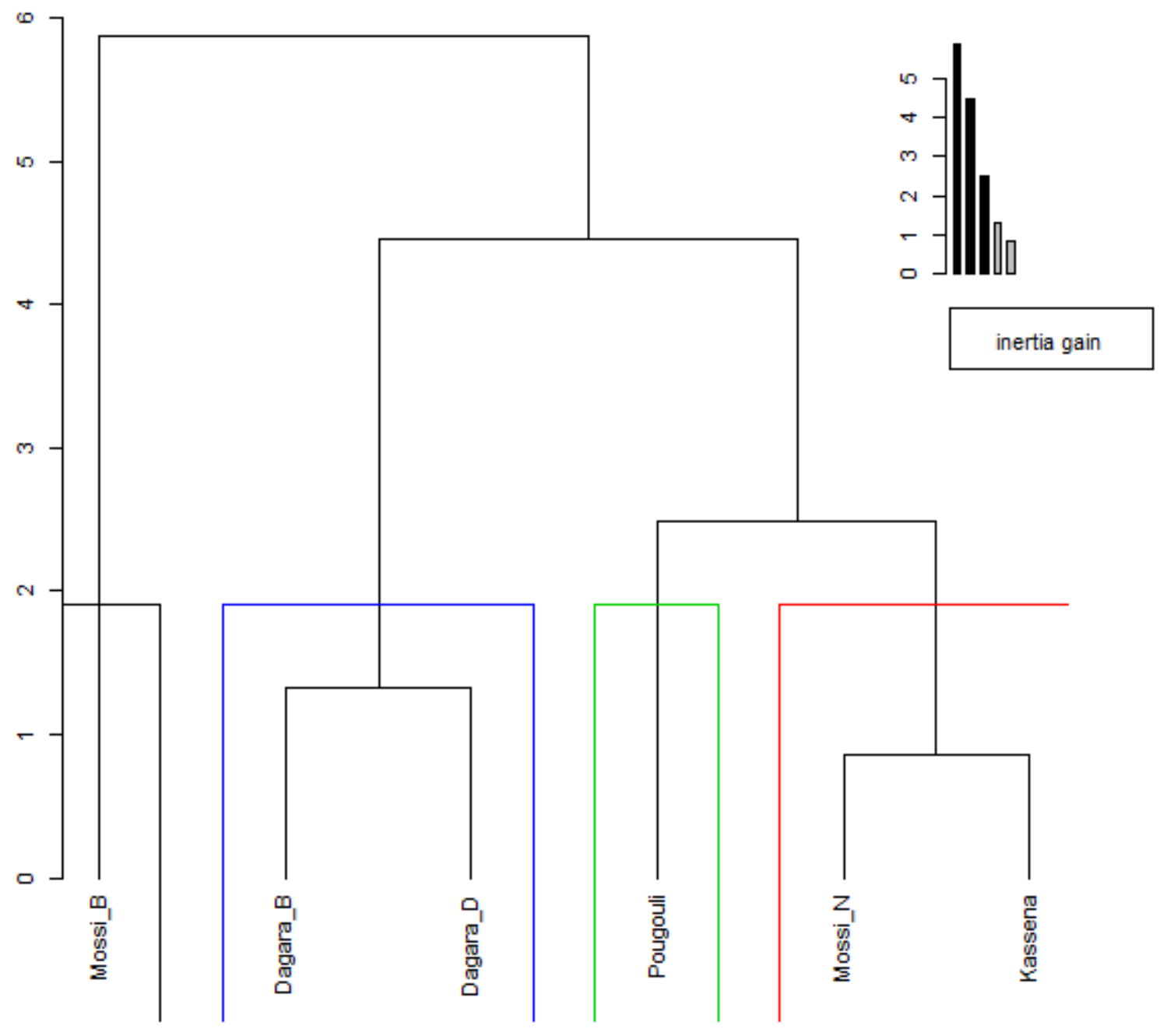

Figure 5

Sociocultural groups scores clustered according to similarity of ecosystems services citations. Dagara_B: Dagara of TWRB (native); Dagara_D: Dagara of CAD (native); Mossi_N: Mossi of GRN(migrant); Mossi_B: Mossi of TWRB (migrant). 


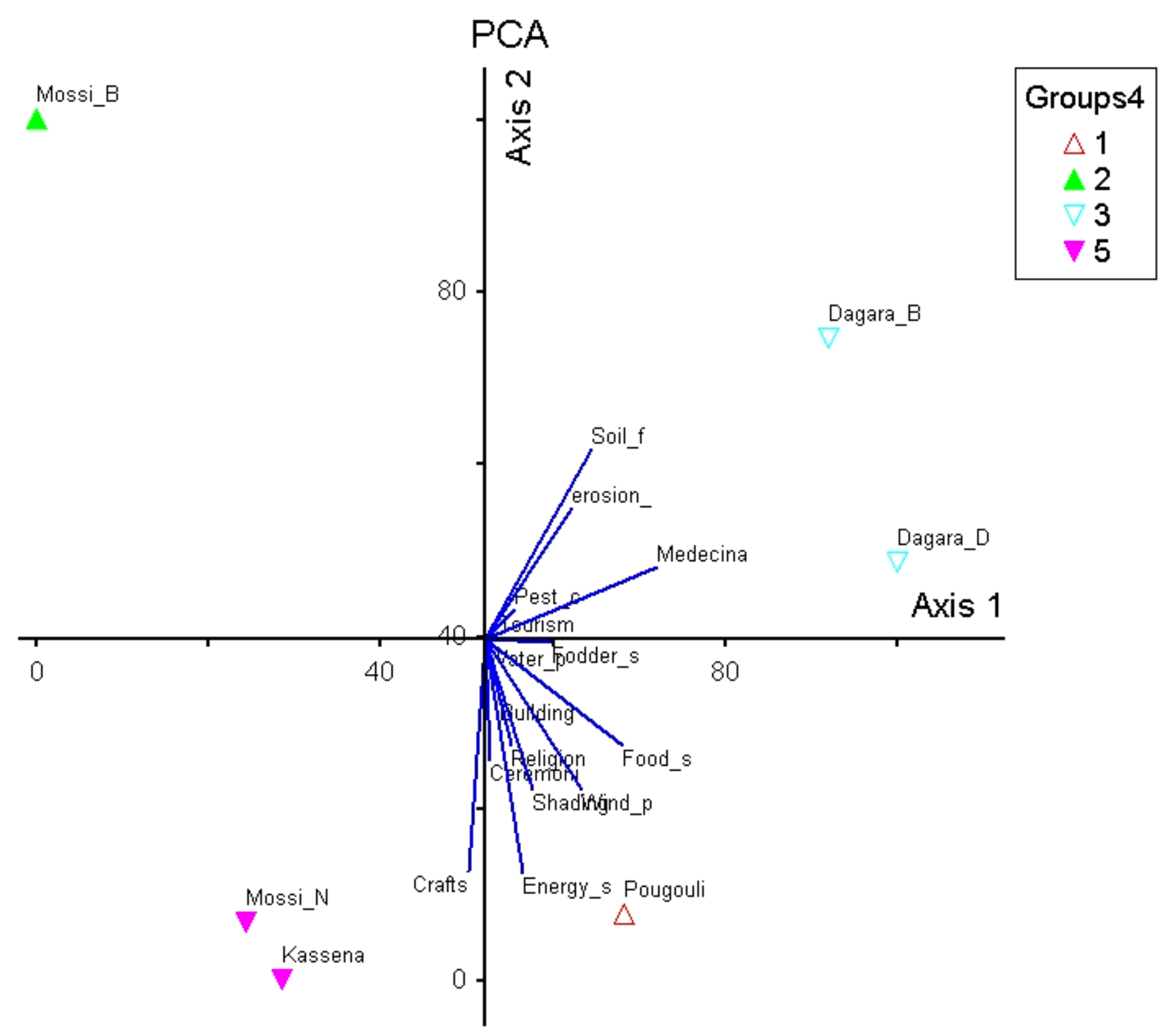

Figure 6

PCA of sociocultural groups and knowledge on ecosystem services Soil_f: soil fertility; Pest_c: pest control; Erosion_: erosion prevention; Fodder_s: fodder supply; Medicina: medicinal use; Food_s: food supply; Energy_s: energy supply; Wind_p: wind protection; Water_p: water purification; Dagara_B: Dagara of TWRB; Dagara_D: Dagara of CAD; Mossi_N: Mossi of GRN; Mossi_B: Mossi of TWRB. 


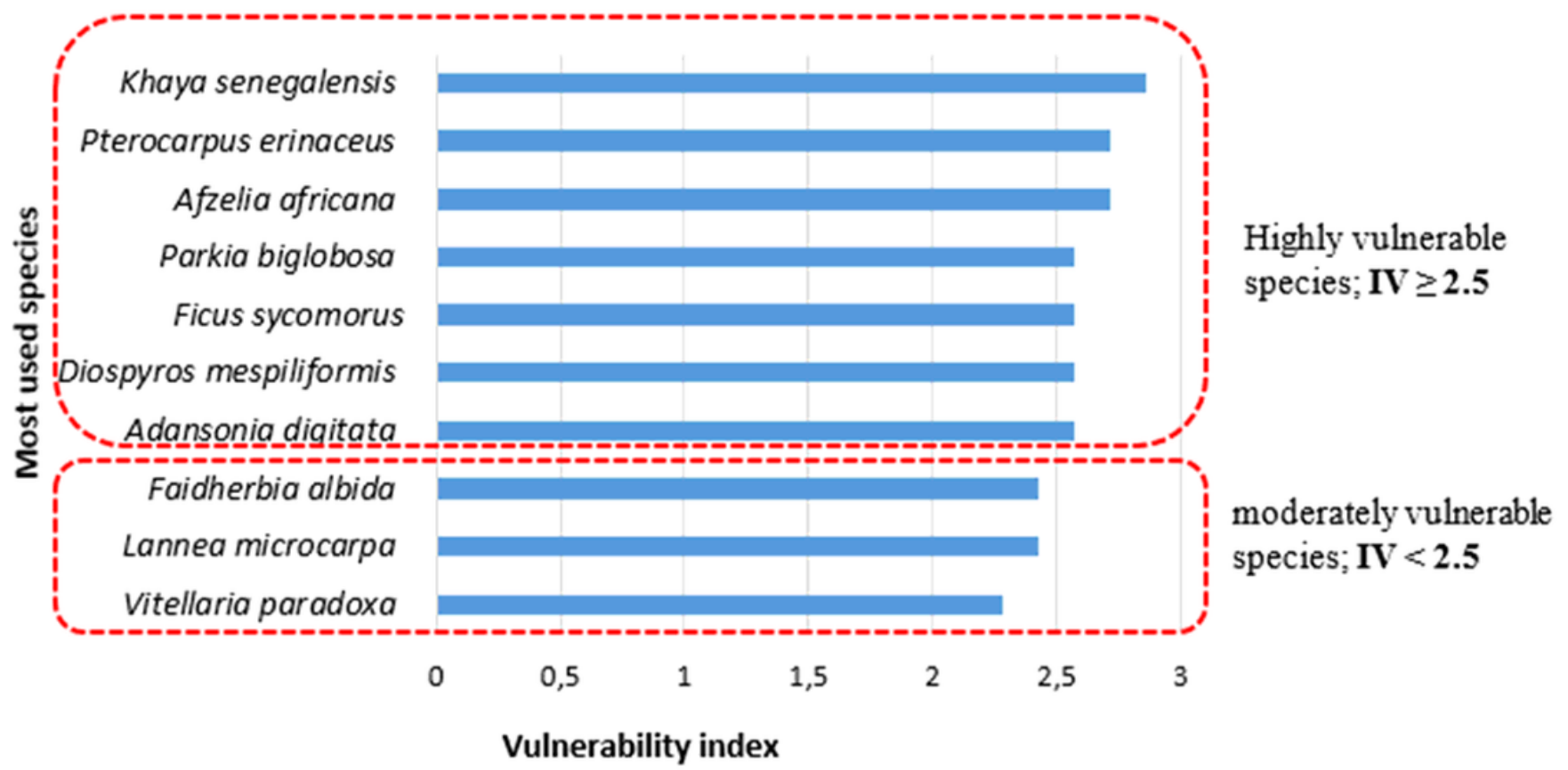

Figure 7

Vulnerability index of the most used species 